\title{
Probiotics: A Promising Anti-Cancer Agent
}

\author{
Bhuvan Saud ${ }^{1 *}$ and Saroj Adhikari ${ }^{2}$ \\ ${ }^{1}$ Department of Medical Laboratory Technology, Janamaitri Foundation Institute of Health Sciences, Nepal \\ ${ }^{2}$ Manmohan Cardiothoracic Vascular and Transplant Center; Tribhuvan University, Nepal
}

Submission: August 01, 2018; Published: August 23, 2018

*Corresponding author: Bhuvan Saud, Department of Medical Laboratory Technology, Janamaitri Foundation Institute of Health Sciences (JFIHS), Hattiban, Lalitpur, Nepal; Email: link2bhuvan@gmail.com

\begin{abstract}
Even in today's modern era with sophisticated diagnostic and treatment facilities both infectious diseases and non-infectious disease are still a major threat to human health and well-being. The readily available probiotics have been under looked as an agent for improving human health and rendering immunity against these diseases. Probiotics are bacteria, molds and yeasts found in dairy products, plants, meat products, sewage, manure, humans and animals. Probiotic has the ability to improve health condition like gastrointestinal infections, genitourinary infections, allergies, urinary tract infections, certain bowel disorders, immune disorders, Helicobacter pylori infection and cancer etc. The bacterial components or metabolites of probiotics play an important role in prevention of variety of diseases. Cancer is one of the major threats to the human health. Through different mechanisms, probiotics in the form of single bacterial strain or a combination of many have shown anticancer activity in humans. Promising results are being obtained from recent research on anticancer activity of probiotics. Thus, the aim of this present review paper is to highlight the role of probiotic bacteria against cancer.

Keywords: Probiotic bacteria; Human health; Dairy products; Anti-carcinogen; Lactobacilli; Cancer; Lactobacillus rhamnosus; Bifidobacterium longum; Bifidobacterium breve; Saccharomyces boulardii; Bifidobacterial; Collaboration; B-Glucuronidase; Lactobacillus acidophilus; Azoreductase; L. casei; L. Acidophilus; Bacillus polyfermenticus; Gundruk; Sinki; Kimchi Taama
\end{abstract}

Abbreviations: WHO: World Health Organization; L: Lactobacillus; B: Bacillus; MAPK: Mitogen-Activated Protein Kinase; NK: Natural Killer cell

\section{Introduction}

Nobel Prize winner Élie Metchnikoff in early $20^{\text {th }}$ century observed that people consuming fair amount of fermented milk products lived longer than average in Bulgaria. Lilly and Stillwell coined the word 'probiotics' in 1965 as growth promoting factor. The word probiotic refers to the mechanisms involved in selectively removing pathogens. According to World Health Organization (WHO), live microorganisms which when administered into host in sufficient amount will provide health benefits are called probiotics. From the time of early human civilization probiotics have always been used in one or another form. Currently, realizing the health benefits of probiotics pills, food, powders and infant formula containing beneficial microorganisms have been availed commercially. It has been proven that most of commercially available probiotics are safe and improve human health [1-4].

Microorganisms should have some basic properties to be considered as probiotic. Probiotics are non-pathogenic and nontoxic to the host. Their intake dose should be fairly large, and they should be viable. Likewise, they should have the ability to survive in the acidic and basic environment of the stomach and duodenum respectively. Also, they should be able to stimulate the immune process within the body and should be able adhere to the gut epithelium and capable of exhibiting anti-cancerous activity. The following bacteria are being used as probiotics by different industries commercially in several countries. Lactobacillus rhamnosus GG in Finland, Lactobacillus johnsonii Lal in Switzerland, Lactobacillus casei Shirota in Japan, Lactobacillus acidophilus NCFM, Saccharomyces boulardii and $L$. casei CRL-43i Gilliland (La-Mo) in USA, Lactobacillus plantarum 299V in Sweden, L. rhamnosus 271 L. in France, Lactobacillus delbruekii sub species bulgaricus 2038 and Streptococcus thermophilus 1131, Lactobacillus acidophilus SBT-2062, Bifidobacterium longum SBT-2928 and Bifidobacterium breve in Japan. Saccharomyces boulardii yeast also show beneficial effect on human health $[5,6]$.

It has been observed that colonic microflora produces many mutagens, tumor promoters and carcinogens utilizing dietary precursors and endogenously produced precursors [7]. 
Human faeces have shown mutagenic activities and also produce genotoxigenic substances of bacterial origin. Altering the gut microflora by the use of probiotics through dietary supplement will decrease the risk of colon cancer by interfering the carcinogenesis process. Increasing the numbers of lactobacilli and/or bifidobacteria in the colon by use of probiotics has shown to modify microflora of the colon. The natural products found in probiotics have drawn the attention of clinical nutritionists, scientists and industrialists to work in collaboration to utilize probiotics to develop drugs targeted against cancer which would show minimal or no side effects [7-10].

\section{Anti-carcinogenic Effects of probiotics}

There are several environmental, chemical pollutants, biological agents and genetic factors that subsequently lead to cancer. According to WHO, cancer is the second leading cause of death. Globally, 8.8 million deaths in 2015 were due to cancer. Among these deaths around $70 \%$ occur in low and middleincome countries. Probiotics are low cost, easily available, anti-pathogens and anti-cancerous microorganisms. The highly valuable probiotics can be availed locally by using traditionally fermented foods and this can improve human health and prevent cancer [11].

Various studies have revealed the processes by which probiotics exhibit anticancer activity. The ability of probiotics to act as anti-carcinogenic agent is supported by its ability to affect bacterial enzyme activity, to act as antigenotoxic agent both in-vitro and in-vivo [9]. Various strains of Lactobacillus and Bifidobacterium, their cellular components and metabolites have shown to decrease DNA damage in colon cells. Bifidobacterium longum and Lactobacillus acidophilus showed decreased activity of pro-carcinogenic enzyme and increased enzymatic activities of $\beta$-glucuronidase, nitroreductase and azoreductase [12-14]. Milk fermented with L. acidophilus La1 and enhance immune stimulation. Butyrate produce from probiotics acts on cancer cells by decreasing proliferation and increasing apoptosis $[15,16]$.

Randomized trial conducted by Aso et al. [17] on patients who had their bladder tumor removed showed decreased recurrence of the tumor, $57 \%$ in subjects receiving L. casei compared to control subjects who had $83 \%$ recurrence $[17,18]$. Another in-vitro study showed that, probiotic strains of L. acidophilus LA102 and L. casei LC232 show anti-proliferative and cytotoxic activity against cell lines of colorectal cancer (Caco-2 and HRT18). Among patients with colorectal cancer, increased number of T-helper cells and NK cells have been seen with $L$ casei which may have important role in suppressing tumor development. In East Asia, Bacillus polyfermenticus has been used for the management of gastrointestinal disorders. In vitro and in-vivo B polyfermenticus showed that it suppresses cancer through the reduction of ErbB2 and ErbB3 and their downstream signaling molecules E2F-1 and cyclin D1[18-20].
In human, high expression of ErbB2 is responsible for bladder, breast, colon, and lung cancer. In addition, another study showed that L. plantarum can be a potential candidate for oral cancer therapy by increasing mRNA expression of Phosphatase and Tensin homolog (PTEN) and down regulation of mRNA expression and Mitogen-Activated Protein Kinases (MAPK). The probiotics mixture VSL\#3 suppress the Cyclooxygenase-2 (COX2) expression in Colo320 and SW480 intestinal epithelial cells. Anti-proliferative and pro-apoptotic activity of human-derived Lactobacillus reuteri ATCC PTA 6475 has also been studied. Promotion of apoptosis in L. reuteri is done by enhancing the activity of mitogen-activated protein kinase (MAPK) including c-Jun N-terminal kinase and p38 MAPK signaling cascade [2124].

\section{Conclusion}

Globally, cancer is one of the major factors increasing morbidity and mortality. The cost of chemotherapy and its management also increases economic burden in the patients. Probiotics and their metabolites can be used as alternative remedies for the prevention of the cancer. Probiotic organisms show anti-cancerous activity by producing anti-tumorigenic compounds, reduce the effect of carcinogens by binding to them or reducing the absorption of mutagens through intestine and enhancing the immune system of the host. Majority of deaths due to cancer occur in lower and middle-income countries and the people either do not have quality testing and treatment facility or cannot afford costly treatment. It has been seen that traditionally used fermented foods have high concentration of probiotics. These foods can be prepared using low cost food items and have great health benefits. Fermented foods like gundruk, sinki, kimchi, taama, curd and many more have been used for centuries and they contain large number of probiotics. Thus, promoting the use of locally fermented foods can help reduce the risk of cancer remarkably.

\section{References}

1. Mackowiak P A (2013) Recycling Metchnikoff: probiotics, the intestinal microbiome and the quest for long life. Front in public health 1: 52.

2. Lilly D M, Stillwell RH (1965) Probiotics: growth-promoting factors produced by microorganisms. Science 147(3659): 747-748.

3. Joint FA (2001) WHO Expert consultation on evaluation of health and nutritional properties of probiotics in food including powder milk with live lactic acid bacteria. Córdoba, Argentina, Geneva, Switzerland 1: $1-4$.

4. Yu AQ, Li L (2016) The potential role of probiotics in cancer prevention and treatment. Nutr cancer 68(4): 535-544.

5. Suvarna VC, Boby VU (2005) Probiotics in human health: A current assessment. Current science 88(11): 1744-1748.

6. McFarland LV (2006) Meta-analysis of probiotics for the prevention of antibiotic associated diarrhea and the treatment of Clostridium difficile disease. Am j gastroenterol 101(4): 812.

7. Rowland IR (1995) Toxicology of the colon: role of the intestinal microflora. Human colonic bacteria: role in nutrition, physiology and pathology. Boca Raton CRC Press. 13: 155-74. 
8. M Venturi, R J Hambly, B Glinghammar, J J Rafter, I R Rowland (1997) Genotoxic activity in human faecal water and the role of bile acids: a study using the alkaline comet assay. Carcinogenesis 18(12): 23532359.

9. Burns AJ, Rowland IR (2000) Anti-carcinogenicity of probiotics and prebiotics. Curr issues intest microbiol 1 (1): 13-24.

10. Kerry RG, Patra JK, Gouda S, Park Y, Shin HS, Das G (2018) Benefaction of probiotics for human health: A review. Journal of food and drug analysis 26(3): 927-939.

11. http://www.who.int/news-room/fact-sheets/detail/cancer

12. Pool-Zobel BL1, Neudecker C, Domizlaff I, Ji S, Schillinger U, et al. (1996) Lactobacillus-and bifidobacterium-mediated antigenotoxicity in the colon of rats. Nutr cancer 26(3): 365-380.

13. Benno Y, Mitsuoka T (1992) Impact of Bifidobacteriumlongum on human fecal microflora. Microbiol immunol 36(7): 683-694.

14. Goldin BR, Gorbach SL (1984) The effect of milk and lactobacillus feeding on human intestinal bacterial enzyme activity. Am j clin nutr 39(5): 756-761.

15. Link-Amster H, Rochat F, Saudan KY, Mignot O, Aeschlimann JM (1994) Modulation of a specific humoral immune response and changes in intestinal flora mediated through fermented milk intake. FEMS Immunol Med Microbiol 10(1): 55-63.

16. Rivière A, Selak M, Lantin D, Leroy F, De Vuyst L (2016) Bifidobacteria and butyrate-producing colon bacteria: importance and strategies for their stimulation in the human gut. Front microbiol 7: 979.

17. Aso Y, Akazan H (1992) Prophylactic effect of a Lactobacillus casei preparation on the recurrence of superficial bladder cancer. BLP Study Group. Urol int 49(3): 125-129.
18. Sawamura A (1994) Enhancement of immuno-activities by oral administration of Lactobacillus casei in colorectal cancer patients. Biotherapy 8: 1567-1572.

19. Awaisheh SS, Obeidat MM, Al-Tamimi HJ, Assaf AM, EL-Qudah JM, et al. (2016) In vitro cytotoxic activity of probiotic bacterial cell extracts against Caco-2 and HRT-18 colorectal cancer cells. Milk and dairy products in human nutrition 69: 33-37.

20. Ma EL, Choi YJ, Choi J, Pothoulakis C, Rhee SH, et al. (2010) The anticancer effect of probiotic Bacillus polyfermenticus on human colon cancer cells is mediated through ErbB2 and ErbB3 inhibition. Int j cancer 127(4): 780-790.

21. Kamath S, Buolamwini J K (2006) Targeting EGFR and HER-2 receptor tyrosine kinases for cancer drug discovery and development. Medicinal research reviews 26(5): 569-594.

22. Asoudeh-Fard A, Barzegari A, Dehnad A, Bastani S, Golchin A, et al (2017) Lactobacillus plantarum induces apoptosis in oral cancer KB cells through upregulation of PTEN and downregulation of MAPK signalling pathways. BioImpacts 7(3):193-198.

23. Otte JM, Mahjurian-Namari R, Brand S, Werner I, Schmidt WE, et al. (2008) Probiotics regulate the expression of COX-2 in intestinal epithelial cells. Nutr cancer 61(1): 103-113.

24. Iyer C, Kosters A, Sethi G, Kunnumakkara AB, Aggarwal BB, et al. (2008) Probiotic Lactobacillus reuteri promotes TNF-induced apoptosis in human myeloid leukemia-derived cells by modulation of NF- $\kappa \mathrm{B}$ and MAPK signalling. Cell microbiol 10(7):1442-1452.

\section{Your next submission with Juniper Publishers will reach you the below assets}

- Quality Editorial service

- Swift Peer Review

- Reprints availability

- E-prints Service

- Manuscript Podcast for convenient understanding

- Global attainment for your research

- Manuscript accessibility in different formats ( Pdf, E-pub, Full Text, Audio)

- Unceasing customer service

Track the below URL for one-step submission https://juniperpublishers.com/online-submission.php 